\title{
MOST RADIOCARBON DATES I
}

\section{E F NEUSTUPNY}

Czechoslovak Academy of Sciences, Archaeological Institute, Prague and $\mathrm{K}$ VESELY*

Brown Coal Research Institute,

\author{
Laboratory of Applied Nuclear Physics, Most
}

The Laboratory of Applied Nuclear Physics of the Brown Coal Research Institute in Most started the radiocarbon dating of archaeologic to 1974 .

Samples of compact wood to be dated were filed to remove surface layers and then were treated in $3 \mathrm{~N}$ hydrochloric acid for 48 hours, after which they were carbonized in an iron retort at $560^{\circ} \mathrm{C}$ for 2 hours. Badly preserved wood, charred wood, charred grain, and charcoal were mechanically cleaned and treated for 24 hours in $3 \mathrm{~N}$ hydrochloric acid and for 24 hours longer in $2 \%$ sodium hydroxide. The samples were then washed in distilled water, acidified by hydrochloric acid to $\mathrm{pH} \leqq 4$, and carbonized. Charcoal obtained in this way was filled into a steel reaction vessel together with an excess of metalic lithium and heated slowly up to $800^{\circ} \mathrm{C}$, similar to the procedure described by Tamers (1969). The phoric acithium carbide was decomposed by dead water with phosthe bencid and the liberated acetylene was catalytically trimerized into product of after Noakes et al (1963). The pearl-type catalyst NEU, The prepared benzene Co, was used (Pietig and Scharpenseel, 1966). analysis it contained only $0.04 \%$ pure, according to gas-chromatographic and $0.08 \%$ water. All the benzene prepared fon noromatic hydrocarbon ferred into a nylon trom each sample was transwere added, $8 \mathrm{mg}$ and without being diluted. PBD and the POPOP samples were prepared by per $\mathrm{lg}$ of benzene, respectively. Reference oxalic acid sered oxidation of the U S NBS oxalic acid standard of modern carbon, followed by reaction of the released carbon dioxide with metalic lithium (Barker, 1953) at $650^{\circ} \mathrm{C}$ and then in the same way as the samples of unknown age. Background samples were prepared from north-bohemian brown coal by means of the same method as archaeologic charcoal samples.

Samples were counted in an Intertechnique liquid scintillation counter Model SL-30. Counting efficiency is ca $64 \%$, using the part of spectrum above the end-point of tritium. Background is from 9 to $13 \mathrm{cpm}$, accordto $95 \%$ of NBS of the sample benzene. The net count rate, corresponding measured set contained acid standard, is $8.03 \pm 0.03 \mathrm{cpm} / \mathrm{g}$ carbon. Each samples of differtained 1 or 2 reference samples, from 3 to 5 background

(

Komenského 9, PO Box A-41, 04061 Košice 
Ages were calculated according to the formula:

$$
\tau=18503 \operatorname{lgd} \frac{0.95 \mathrm{~m}_{\mathrm{S}}\left(\mathrm{R}-\mathrm{B}_{\mathrm{R}}\right)}{\mathrm{m}_{\mathrm{R}}\left(\mathrm{S}-\mathrm{B}_{\mathrm{S}}\right)}
$$

where $m_{S}$ and $m_{R}$ are, respectively, masses of the benzene in the unknown sample and in the reference sample in grams, calculated as arithmetic averages of the values, observed before and after the counting. $S$ and $R$ are average count rates of the unknown sample with background, after elimination of wrong values, based on the 3 sigma rule, and $B_{S}$ and $B_{R}$ are background rates corresponding to masses $m_{S}$ and $m_{R}$. $B_{S}$ and $B_{R}$ were calculated (Veselý et al, 1973) or graphically interpolated from results of background counts. The formula is adequate for benzene sample mass between 3 and $17 \mathrm{~g}$.

All listed dates are based on the Libby half-life value of $5570 \mathrm{yr}$ and referred to 1950 . The dates are not corrected for ${ }^{13} \mathrm{C}$. The reported mean errors are calculated by the formula:

$\sigma=8036\left[\left(\frac{\sigma \mathrm{S}-\mathrm{B}_{\mathrm{S}}}{\mathrm{S}-\mathrm{B}_{\mathrm{S}}}\right)^{2}+\left(\frac{\sigma \mathrm{R}-\mathrm{B}_{\mathrm{R}}}{\mathrm{R}-\mathrm{B}_{\mathrm{R}}}\right)^{2}+\left(\frac{\sigma \mathrm{m}_{\mathrm{S}}}{\mathrm{m}_{\mathrm{S}}}\right)^{2}+\left(\frac{\sigma \mathrm{m}_{\mathrm{R}}}{\mathrm{m}_{\mathrm{R}}}\right)^{2}\right]^{0.5}$

where $\sigma \mathrm{S}-\mathrm{B}_{\mathrm{S}}, \sigma \mathrm{R}-\mathrm{B}_{\mathrm{R}}, \ldots$, are theoretical standard statistical deviations of the values $S-B_{S}, R-B_{R}, \ldots \ldots$

The laboratory received samples with no information, and carried out measurements without knowing even the approximate age of samples.

\section{ACKNOWLEDGMENTS}

We thank J Peniška and M Hrubý for their careful assistance during the construction of the benzene synthesis vacuum line and laboratory operations.

\section{SAMPLE DESCRIPTIONS}

$2835 \pm 110$

\section{MOC-20. Počerady, Pit 1}

885 BC

Charcoal from a piriform pit at Počerady, dist Louny, containing no datable archaeol finds. Nearby features could be dated to the La Tène period, 2nd half of 1st millennium BC. Excavated by E Neustupný in 1966. Comment: considerably contaminated. Date corresponding to Late Bronze age, absent at the site.

MOC-26. Rusovce

Charred grain strewn over last habitation layer of the Roman camp Gerulata, Rusovce, Bratislava dist. Excavated in 1967 by J Dekan. Comment: should be 5 th century AD. Date agrees with archaeol estimate.

MOC-27. Kadañ, Pit 12

$1560 \pm 80$

Charcoal from Pit 12, Jezerka at Kadan, Chomutov dist. Site revealed finds mostly from Hallstatt $\mathrm{D}$ and Early La Tène periods, 6th to 
5 th centuries BC. Pit 12 was originally believed to be of this age. Coll 1968 by V Kruta. Comment: considerably contaminated and attacked by mildew. Date sharply disagreed with archaeol expectation. Finds from Pit 12 were reinspected and found to contain sherds from possibly the 5th century AD. This is corroborated by P-1915: $1560 \pm 50(\mathrm{R}, 1975$, $\mathrm{v} 17, \mathrm{p} 199$ ) for another part of the same sample, and by a thermoluminiscence date $\mathrm{AD} 400$. obtained on a sherd from Pit 12 by J Kvasnička (pers commun).

MOC-44. Most, No. 240

$680 \pm 70$

Charred grain from a clestroyed oven in the yard of House No. 240 in Most, Most dist. Archaeol age was believed to be 13 th century AD. Coll 1972 by J Klápště. Comment: date agrees with archaeol estimate.

\section{MOC-52. Rvenice}

$2655 \pm 50$

Rotted wood from a massive beam used for construction of burial chamber at Rvenice, Louny dist. Grave belonged to "princely" class of the Bylany culture (Hallstatt $\mathrm{C}$ period, 7th century BC archaeol chronology). Coll 1961 by D Koutecký. Comment: date, especially if calibrated, suggests older age, 9th century BC, than expected archaeol. This is surprising but agrees with other dates obtained in Philadelphia for Hallstatt B2 and D periods: P-1907: $2730 \pm 60$ Hallstatt B2, P-1913: $2630 \pm 60$ and P-1914: $2550 \pm 50$ Hallstatt D (R, 1975, v 17, p 198).

\section{Mohelnice series}

An extensive Neolithic site was partly destroyed by a sandpit at Mohelnice, N Moravia, from 1971 to 1973. It lay near the upper course of the Morava $\mathrm{R}$, whose water-table could be reached by wells several $\mathrm{m}$ deep. The wells contained much organic material suitable for radiocarbon dating.

\section{MOC-69. Mohelnice CCLV}

$4800 \pm 70$ 2850 BC

Wet wood from Eneolithic well CGLV at Mohelnice, šumperk dist. Pottery from feature probably belongs to an early phase of the TRB culture. Coll 1971 by R Tichý. Comment: agrees well with expected archaeol age. Groningen measurement of the same sample is $4985 \pm 40$ : GrN-6604.

\section{MOC-70+91. Mohelnice CCLIV}

$6220 \pm 80$

Wet wood from Neolithic well CCLIV at Mohelnice, šumperk dist. Pottery fragments from well belong to a somewhat developed earliest phase of Linear Pottery culture. Coll 1971 by R Tichý. Comment: as sample MOG-70 did not contain sufficient amt of carbon, only $2.6 \mathrm{~g}$ benzene yield, it was mixed in benzene form with sample MOC-91, from the same piece of wood. Both samples were measured together. Resulting 
date agrees well with archaeol expectation and with a Groningen measurement of another sample from same well, GrN-6610: $6240 \pm 65$ вр.

\section{MOC-91. Mohelnice CCLIV}

$6330 \pm 140$

Description as MOC-70+91. Comment: separate count is less accurate than MOC-70+91, because of smaller mass.

\section{MOC-71. Mohelnice CCLVI}

$3340 \pm 50$

1390 BC

Wet wood from a prehistoric well, feature CCLVI, at Mohelnice, Sumperk dist. Wood was presumably shaped by means of a metalic tool and is therefore believed to be of Bronze age date. Coll 1972 by R Tichý. Comment: date indicates Middle Bronze age. Another sample from the same well was measured in Groningen, giving 3875 вр (pers commun).

General Comment: as everything inside the wells was perfectly conserved there was some doubt as to their antiquity; prehistoric pottery could have been deposited secondarily. Radiocarbon dates showed that the wells did belong to the Neolithic, Eneolithic, and Bronze ages, despite their modern appearance. Wells from those periods are to be expected in other sites with similar geol conditions. They are of paramount archaeol interest in view of the fact that they contain well preserved artifacts of organic materials and wooden beams.

\section{Meclov series}

Meclov-Březí is an extensive site in W Bohemia. Excavations led by E C̆ujanová revealed finds from beginning of Middle Bronze age, ca 1900 BC calibrated radiocarbon chronology. The pottery, however, is badly preserved, weathered surface, and comes mostly from a shallow cultural layer (Čujanová, 1967).

\section{MOC-88. Meclov, Hut 1}

$$
1890 \pm 70
$$

Charcoal from a fireplace in Hut 1. Comment: radiocarbon age is ca 2000 yr later than expected archaeol. Cf General Comment, below.

\section{MOC-89. Meclov, Pit 32}

$$
1525 \pm 70
$$

Charcoal from a hearth in Pit 32. Comment: same sample as MOG-98 and LJ-2501: $1537 \pm 50$ (pers commun). Ca 2300 yr later than expected archaeol. Cf General Comment, below.

MOC-98. Meclov, Pit 32

$1410 \pm 80$

Charcoal from a hearth in Pit 32. Comment: same sample as MOC-89.

MOC-90. Meclov, Pit 36

$$
2280 \pm 60
$$

330 BC

Charcoal from a fireplace in Pit 36. Comment: same sample as MOC-97. Ca 1600 yr later than expected. Cf General Comment, below. 


\section{MOC-97. Meclov, Pit 36}

Charcoal from a fireplace in Pit 36. Comment: same sample as MOC-90.

General Comment: other samples from Meclov were measured by $\mathrm{H}$ Suess in La Jolla and thermoluminiscence, preliminary results, was measured by J Kvasnička (pers commun). The evidence may be summarized as follows:

\begin{tabular}{lccc}
\hline Feature & La Jolla & Most & $\begin{array}{c}\text { Thermoluminiscence } \\
\text { dates BP }\end{array}$ \\
\hline Pit 36 & & $2300 \pm 70:$ MOC-97 & $3867 \pm 390$ \\
\hline Hut 1 & & $1890 \pm 70:$ MOC-88 & $1410 \pm 170$ \\
\hline Pit 32 & $1537 \pm 50:$ LJ-2501 & $1525 \pm 70:$ MOC-89 & \\
\hline Hut 3 & $1537 \pm 50:$ LJ-2499 & $1410 \pm 80:$ MOC-98 & \\
\hline Pit 1959 & & & $1500 \pm 220$ \\
\hline
\end{tabular}

The only non-archeol evidence for Middle Bronze age occupation is the thermoluminiscence date for Pit 36. Radiocarbon samples from the same feature, however, indicate 5th century BC, which is the Early La-Tène period in archaeol classification. Thermoluminiscence date for Hut 1 also differs from the corresponding radiocarbon age. La Jolla and Most agree perfectly on a group of dates, both radiocarbon and thermoluminiscence, for Pit 32, Hut 3, and Pit 1959: an occupation is definite ca AD 400. Traditional archaeol methods discovered only 1 occupation while radiocarbon and thermoluminiscence dating clearly shows at least 3 .

\section{REFERENCES}

Barker, Harold, 1953, Radiocarbon dating: large scale preparation of acetylene from organic material: Nature, v 172, p 631-632.

Čujanová, E, 1967, Der donauländische Vorhügelgräberhorizont $\mathrm{A}_{2} \mathrm{~B}_{1}$ : Památky archeologické, v LVIII, p 2, 381-412.

Noakes, J E, Isbell, A F, Stipp, J J, and Hood D W, 1963, Benzene synthesis by low temperatures catalysis for radiocarbon dating: Geochim et Cosmochim Acta, v 27, p 797-804.

Pietig, F and Scharpenseel, H W, 1966, Alterbestimmung mit dem Flüssigkeits-Szintillations-Spektrometer, Ein neuer Katalysator zur Benzolsynthese: Atompraxis, v 12, no. 12 , p $95-97$.

Tamers, M A, 1969, Instituto Venezolano de Investigaciones Cientificas natural radiocarbon measurements IV: Radiocarbon, v 11, p 396-422.

Veselý, K et al, 1973, Výzkum měreni velmi nízkých koncentrací tritia a uhlíku 14 ve vzorcích vod metodou kapalných scintilátorů s využitím doplnkových fyzikálně chemických metod: Research Rept BCRI No. 171/73, BCRI Most. 